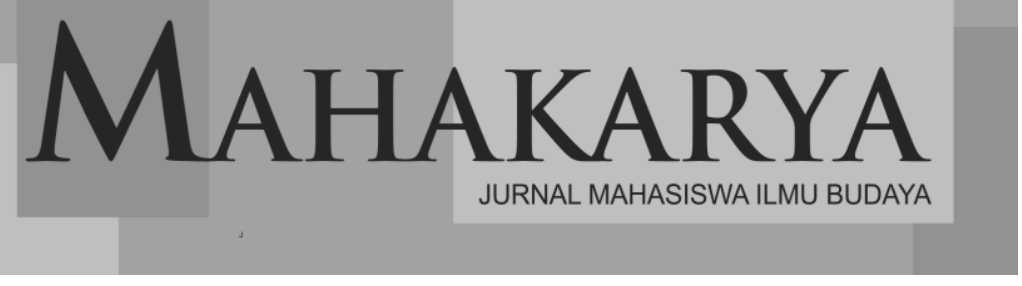

Volume 1 Nomor 1 - Maret 2020

\title{
METODE CERITA DALAM PEMBELAJARAN KETERAMPILAN BERBICARA BAHASA ARAB
}

\author{
Karina Nur Aini \\ karinanuraini.91@gmail.com \\ Laily Fitriani \\ laily@bsa.uin-malang.ac.id \\ Program Studi Bahasa dan Sastra Arab UIN Maulana Malik Ibrahim
}

\begin{abstract}
The method is a step or a way to make teachers assisted in conveying subject matter and to be able to achieve learning goals easily. However, if the method chosen is not in accordance with the subject matter, it will make it more difficult for students and teachers themselves. In this study aims to investigate / describe a story method that uses the formula $5 \mathrm{w}+1 \mathrm{~h}$ with the help of an image. In this study, the method implemented in this study is a descriptive-qualitative research method by collecting observation data and learning practices. The findings in this study show that there are advantages and disadvantages in using the story method. Here are the advantages of this story method, one of which is to be able to practice listening and speaking skills of learners. The listeners will get a positive impact, as well as getting a new vocabulary from the storyteller in front and the speaker can have the courage to speak in Arabic freely. While the lack of this method of this story, one of which is that it takes a long time to compile a story that is about to be presented.
\end{abstract}

Keywords: story method, speaking skills, Arabic

\section{Pendahuluan}

Bahasa dapat diartikan sebagai keterampilan. Keterampilan yang menuntut para penggunanya untuk mampu mengimplementasikannya secara terus-menerus, karena dengan seringnya seseorang menggunakan bahasanya, maka seseorang tersebut akan lebih cepat terampil dalam berbahasa. Seluruh bahasa manapun takakan pernah lepas dari keempat keterampilan yang telah kita ketahui, yakni keterampilan menyimak, keterampilan berbicara, keterampilan membaca dan keterampilan menulis. Begitu pula dalam pembelajaran bahasa Arab, keempat keterampilan itu disebut dengan maharah istima', maharah kalam, maharah qiro'ah dan maharah kitabah.

Pendapat Al-Ghalayin, bahwa bahasa Arab adalah sebuah kalimat-kalimat yang dipergunakan oleh bangsa Arab untuk menyampaikan pikiran mereka (Al-Ghalayani 2005, 7). Dengan ini dapat dikatakan bahwa bahasa Arab adalah bahasa yang sering digunakan oleh bangsa Arab untuk bertukan pikiran satu dengan yang lainnya.

Pada era yang sudah berkembang ini, Bahasa arab tidak kalah menariknya dengan bahasa Inggris yang telah terkenal sejak dulu kala. Sebagai contohnya, dipondok-pondok pesentren yang lebih dulu dalam membelajarkan para santrinya dengan pembalajaran bahasa Arab. Begitupun dengan sekolah-sekolah umum yang tengah mempraktekan pembelajaran bahasa Arab pada saat ini. Menurut Bahriah, bahwa bahasa Arab ini telah menunjukkan eksistensinya dan peran pentingnya dimata dunia, yaitu sebagai wahana komunikasi dan ajang interaksi di berbagai forum internasional. Kini bahasa Arab sudah sejajar dengan Bahasa-bahasa lainnya yang tidak kalah pentingnya dengan bahasa Inggris (Bahriah 2008, 2). Dengan ini dapat dinyatakan bahwa bahasa Arab itu sangat penting dan perlu untuk dipraktekkan dalam pembelajaran pada era ini.

Perlu kita ketahui bahwa pembelajaran bahasa Arab adalah suatu kegiatan belajar mengajar yang dilakukan pembelajarnya dan pengajarnya guna mencapai tujuan pembelajaran bahasa Arab yang ingin dicapai. 
Untuk itu, seorang pengajar harus mampu dalam menjadikan pembelajarnya tertarik dan berminat dalam pembelajaran berlangsung. Karena banyak dari pembelajar yang memiliki ketakutan pada pembelajaran bahasa Arab, mereka memandang bahwa bahasa Arab adalah mata pelajaran yang sukar untuk dipelajari. Untuk itu para pengajar lebih dituntut untuk dapat lebih kreatif dalam pembelajarannya, mungkin dengan pemilihan metode yang digunakan, atau dari segi media pembantunya, atau dari segi permainanya yang ditambahkan dalam pembelajaran. Ketika seorang pengajar salah dalam memilih metode, media dan lain sebagainya, maka akan membuat pembelajar lebih sulit dalam mempelajarinya dan berdampak buruk pada tujuan pembelajaran yang ingin dicapai. Oleh sebab itu, pengajar lebih harus teliti lagi dalam pemilihannya.

Menurut Sanjaya, bahwa metode adalah suatu cara yang digunakan untuk mempraktekkan perencanaan yang telah dirumuskan dalam kegiatan nyata guna tujuan yang telah disusun tercapai secara optimal (Sanjaya 2008, 147). Dapat dikatakan bahwa metode adalah sebuah langkah atau cara guna memudahkan guru dalam pembelajaran berlangsung dan menurut Ginting, bahwa metode pembelajaran dapat diartikan cara atau pola yang memiliki kekhususan dalam memanfaatkan berbagai prinsip dasar Pendidikan serta berbagai tekni dan sumber daya terkait lainnya agar terjadi proses pembelajaran pada diri pembelajar (Ginting 2008, 42). Dapat diperjelas bahwa, metode pembelajaran adalah suatu cara atau bentuk yang dapat membantu pengajar dalam mengola pembelajaran berlangsung yang berkaitan dengan pembelajar itu sendiri.

Dalam pemilihan metode pembelajaran guru tidak boleh asal dalam memilih metode, harus sangat disesuaikan dengan tujuan pembelajaran sehingga dapat mempermudah para pengajar itu sendiri dalam mengelola kelas dan pembelajar pun dapat mudah dalam menerima pelajaran yang diberikan. sehubungan pembelajaran bahasa Arab adalah pelajaran yang sukar untuk dipelajari maka, penulis ingin menggambarkan metode cerita yang berumusan $5 \mathrm{w}+1 \mathrm{~h}$ ini.

Menurut Dhieni, bahwa bercerita adalah suatu kegiatan lisaniyyah yang ditujukan kepada lawab bicaranya dengan alat bantu ataupun tanpa alat untuk menyampaikan sebuah pesan, informasi ataupun hanya sebuah cerita yang didengarkan dengan perasaan bahagia. Oleh sebab itu, dalam menyampaikan sebuah cerita para penutur seyogyanya menuturkannya dalam bentuk yang menarik sehingga para pedengar seakanakan berada dalam cerita yang diceritakan oleh pencerita, karena dengan cerita yang menarik dan pencerita yang mampu mengekspresikan cerita tersebut maka pendengar akan lebih tertarik dalam menyimaknya.

Sedangkan moeslichatoen berpendapat bahwa metode cerita adalah salah satu langkah dalam menyalurkan pengalaman belajar bagi pembelajar dengan menyuguhkan cerita kepada anak secara lisan (Moeslichatoen 2004). Cerita yang disuguhkannya pun harus memiliki kesan yang menarik dan yang dapat mengundang perhatian penyimaknya, dan tetap dalam koridor tujuan pembelajaran yang hendak dicapai.

Berikut beberapa penelitian yang terkait dengan metode cerita, yang mana pengimplementasiannya sangat efektif dalam pembelajaran cerita ini dan memiliki dampak positive untuk para pembelajarnya, dipaparkan oleh Patimah (2015) yang mana penelitian ini menitik beratkan pada anak jenjang usia Sekolah Dasar menggunakan metode cerita dengan hasil efektif dalam pembelajarannya Kemudian dipertegas oleh Mahliatussikah (2018), yang mana penelitiannya bukan hanya berfokus pada cerita melainkan pembelajaran bahasa Arab dapat dibuatnya dengan bermain dan menanyi yang menitik beratkan pada anak usia dini. Penelitian lainnya oleh Darmila \& Nunzairini (2018), yang peneliti disini ingin mengetahui pengaruh dari metode cerita terhadapat kosa kata yang ditujukan pada anak usia 5-6 tahun. Ditambahi oleh Utami (2018), yang mana penelitian ini berfokuskan pada peningkatan keterampilan menulis cerpen dengan Teknik $5 \mathrm{w}+1 \mathrm{~h}$ dan menggunakan media video klip siswa yang ditujukan pada siswa kelas. Dipertegas oleh penelitian dari Aini (2018), yang penelitian ini berbeda dengan penelitian sebelumnya, jika penelitian sebelumnya terkait dengan anak usia dini maka penelitian ini berfokuskan pada mahasiswa. Penelitian ini menitik beratkan pada dampak pengaruhnya dengan keterampilan berbicara yang menggunakan metode cerita. 
Dari beberapa penelitian diatas, dapat dipertegas bahwa penelitian yang terkait dengan menggunakan metode cerita ini memang sejatinya untuk anak usia dini atau dengan kata lain mayoritas penggunaan metode cerita ini ditujukan pada anak usia dini, akan tetapi orang dewasapun ketika bercerita bahkan medengar cerita juga tidak akan pernah bosan itulah pembeda penelitian ini dengan penelitian yang terdahulu. Untuk itu penulis disini ingin mengambarkan metode cerita guna dapat mengembangkan ide pembelajar menggunakan rumus $5 \mathrm{w}+1 \mathrm{~h}$.

Berdasarkan observasi langsung, penulis menemukan beberapa keganjalan dalam pembelajaran berlangsung yakni kurang mampunya pembelajar dalam mengembangkan idenya ketika bercerita menggunakan bahasa Arab dan ketika peserta didik diperintahkan oleh pengajarnya dalam bercerita menggunakan bahasa Arab yang menggunakan metode langsung dengan pilihan pengajar. Para pembelajar masih kebingungan dalam mengawali cerita tersebut dan terkadang cerita yang diceritakan terlalu monoton sehingga para pencerita tidak termotivasi dan leluasa dalam berbicara Bahasa Arab dan para mendengarpun tidak mendapat informasi baru berupa kosakata yang belum pernah didengar.

Dapat dipertegas kembali, bahwa bercerita sejatinya untuk semua golongan, yang dalam artian tidak menentukan usianya dalam bercerita, karna dari sebuah cerita inilah seseorang akan mendapatkan informasi baru dan dapat pula menjadikan seseorang tersebut lancar dalam berbicara dengan menggunakan rumus $5 \mathrm{~W}+1 \mathrm{~h}$ pencerita akan lebih terbantu dalam mengembangkan ceritanya.

Secara garis besar penelitian ini bertujuan untuk (1) mendiskripsikan tentang metode cerita dengan rumus $5 \mathrm{w}+1 \mathrm{~h}$ yang dikhususkan pada keterampilan berbicara pada mahasiswa; (2) dan mengetahui kekurangan dan kelebihan yang didapat ketika pembelajaran berlangsung dalam kelas dengan menggunakan metode cerita.

\section{Konsep Keterampilan Berbicara Bahasa Arab}

Pada dasarnya, kemampuan berbicara adalah suatu kemahiran dalam menyampaikan maksud dari ide, pikiran, suatu gagasan bahkan isi hati seseorang yang ditujukan kepada lawan bicaranya secara lisaniyyah sehingga keinginan tersebut dapat tersampaikan secara gamblang oleh orang lain. Suhartono $(2005,22)$ menjelaskan bahwa bicara adalah suatu penyampaian yang memiliki maksud tertentu dengan menuturkan bunyibunyi artikulasi dalam mengekspresikan, menyampaikan, serta menegaskan maksud yang ingin disampaikan berupa ide, pikiran, serta perasaan.

Dalam kamus Besar Bahasa Indonesia (KBBI 2005, 165) bahwa kemampuan berbicara adalah "ber-omong, ber-cakap, ber-bahasa, mengemukakan isi pikiran, menuturkan suatu yang dituju". Dengan ini bicara adalah sebagai bentuk komunaksi yang paling efektif dalam mengutarakan segala halnya dengan lawan bicara.

Keterampilan berbicara atau yang dikenal dalam Bahasa Arab yakni maharah alkalam. Hermawan $(2011,135)$ berpendapat bahwa maharah al-kalam atau keterampilan berbicara merupakan suatu system berupa tanda-tanda yang dapat didengar dan dilihat serta mengerahkan seluruh otot tubuh manusia dalam menyampaikan pikirannya guna dapat memenuhi kebutuhan si penutur.

Tidak jauh berbeda dengan pendapat para ahli sebelumnya, Haryadi dan Zamzani (2000, 72) mengemukakan bahwa keterampilan berbicara adalah sebagai suatu penyampaian maksud dari ide, pikiran, isi hati seseorang kepada orang lain. Untuk itu, jika pembelajaran keterampilan berbicara belum dapat mengutarakan ide-ide dengan menggunakan Bahasa arab maka perlu adanya bantuan untuk dapat mengembangkan idenya.

Dengan ini penulis menegaskan bahwa keterampilan berbicara merupakan penuturan yang dituturkan oleh penutur guna dapat menyalurkan seluruh keresahan dalam pikirannya bahkan kerasahan dalam perasaannya secara lisaniyyah dan ditujukan kepada mitra yang dikehendaki.

Perlu kita ketahui bahwa dalam pembelajaran Bahasa Asing keterampilan berbicara memiliki peranan yang penting, karena dengan penutur dapat menutur Bahasa asing yang ia pelajari maka tujuan dalam mempelajarinya pun tercapai. Penutur atau 
pembelajar dapat mempelajari suatu Bahasa Asing dengan baik, jika pengajarnya memiliki kemapuan dalam membelajarkan pembelajarnya atau penutur secara maksimal dan dengan cara pemilihan metode yang digunakan dalam pembelajaran. Keberhasilan pembelajar terletak pada kedua factor tersebut yakni dari kemampuan seorang guru dan pemilihan metode yang tepat.

Tujuan dalam pembelajaran berbicara Bahasa Arab menurut Taufik $(2016,48)$ yakni sebagai berikut: (1) Guna dapat menjadikan pembelajar mengucapkan suatu ungkapan dalam Bahasa Arab; (2) Dapat menuturkan ungkapan yang berbeda atau bahkan ungkapan yang menyerupai; (3) Dapat membedakan ungkapan dalam bentuk bancaan yang pendek dan yang Panjang; (4) Dapat menyusun kalimat sesuai dengan kaidah nahwu yang tepat; (5) Dapat menuturkan seluruh pikirannya dalam bentuk susunan kalimat Bahasa Arab sesuai dengan kaidahnya; (6) pemilihan dhomir yang tepat dalam penuturannya serta pemilihan kata kerja yang sesuai dengan waktunya; (7) Mampu dalam menggali suatu manuskrip dan literatur Bahasa Arab; (8) Dapat menuturkan suatu ungkapan dengan jelas oleh pendengar dan dapat dipahami oleh diri sendiri; (9) Dapat berpikir dengan cepat atau langsung ketika menuturkan ungkapan Bahasa Arab. Pada keterampilan berbicara Bahasa Arab, menurut Izzan $(2011,116)$ terdapat dua macam dalam pengaplikasiannya, sebagai berikut:

1. Muhadastah (Percakapan)

Muhadastah adalah suatu cara dalam menyuguhkan Bahasa pada pelajaran Bahasa Arab dengan melalui percakapan. Percakapan ini akan menimbulkan suatu interaksi antara pengajar dan pembelajarnya atau antara sesama pembalajarnya. Semakin sering seorang pengajar dan pembelajarnya dalam melakukan interaksi melalui percakapan, maka semakin banyak pula kosa kata baru yang diperoleh.

2. Ta'bir Syafahi (Ungkapan lisaniyyah)

Ta'bir syafahih atau dapat disebut dengan ungkapan lisaniyya adalah suatu latihan dalam mengarang ungkapan lisaniyyah yang bertujuan dalam meningkatkan kemampuan pembelajar pada pengutaraan pikiran dan perasaan yang menggunakan Bahasa Arab.

Penulis menegaskan bahwa dalam dunia pembelajaran Bahasa Asing bukan hanya Bahasa Arab saja, pembelajar dituntut untuk lebih banyak latihan dalam pembelajarannya. Dengan adanya latihan yang sering maka akan berdampak positive untuk pembelajar itu sendiri dari segi keberanian dalam menuturkan sebuah kalimat, menguntaikannya dengan seiindah mungkin dengan menggunakan Bahasa Asing dan dapat pula memiliki kosa kata yang baru.

Untuk itu pada metode cerita ini sangat erat hubungannya dengan ta'bir syafahi yang menjadikan pembelajar dapat bertuturkan Bahasa Arab dan yang menuntut pembelajarnya agar dapat berlatih mengarang sebuah ungkapan lisaniiyah melalui cerita yang telah dikarangnya. Melalui cerita yang disuguhkan dapat pula mengutarakan segala pikirannya dan perasaannya yang dituangkannya pada sebuah cerita yang menarik. Pembelajar dapat mengembangkan ide cerita yang menarik dengan menggunakan bantuan rumusan $5 \mathrm{~W}+1 \mathrm{~h}$, guna dapat merencanakan alur yang akan diceritakan nantinya.

\section{Metode Penelitian}

Metode penelitan yang digunakan oleh peneliti dalam penelitianya mengenai metode cerita dalam pembelajaran keterampilan berbicara Bahasa Arab yakni menggunakan metode pendekatan deskriptif kualitatif yang dimana hasil penelitian ini dipaparkan dengan bentuk kalimat uraian bukan dalam bentuk angka-angka layaknya penelitian kuantitatif. Seperti halnya yang telah diungkapkan oleh Arikunto (1996, 244), menyatakan bahwa kesimpulan akhir dalam studi diskriptif haruslah dalam bentuk katakata atau kalimat, bukan dengan bentuk angka-angka layaknya kuantitatif.

Dipertegas kembali oleh Nawawi dan Martin $(1994,73)$ bahwa metode deskriptif sebagai metode yang menggambarkan suatu keadaan objektif atau peristiwa tertentu berdasarkan fakta-fakta yang tampak atau sebagaimana mestinya yang kemudian 
diiringi dengan upaya pengambilan kesimpulan umum berdasarkna fakta-fakta historis tersebut.

Subjek dalam penelitian ini berkaitan dengan 1 orang guru dan pembelajar yang berjumlah 20 orang yang terdiri dari 9 pembelajar laki-laki dan 11 pembelajar perempuan. Teknik pengambilan data melalui observasi peneliti pada lapangan dengan beberapa catatan yang telah dikumpulan oleh peneliti saat itu. Tujuan inti dari pengamatan ini adalah untuk menggambarkan bagaimana penggunaan metode cerita dengan rumus $5 \mathrm{w}+1 \mathrm{~h}$ yang difokuskan pada pembelajaran keterampilan berbicara Bahasa Arab secara langsung dan menyeluruh.

Berdasarkan pemaparan sebelumnya, peneliti kemudian menganalisis data yang terkumpul. Seperti halnya pemaparan dari Bogdan dalam Sugiyono $(2011,88)$ bahwa dalam pemrosesan analisis data, peneliti mengawalinya dengan sebuah perencanaan dalam pengumpulan data kemudian menganalisis atas data-data dari hasil penelitian tersebut. Maksud dari pengumpulan data disini ialah pengumpulan dari seluruh informasi yang telah didapatkan dalam kegiatan observasi diawal.

Peneliti disini mengambil data dengan menggunakan data obeservasi dan ketika praktek belajar berlangsung. Adanya metode penelitian ini, diharapkan dapat diketahui secara akurat tentang pembelajaran Bahasa Arab. Untuk mendapatkan data penting ini, didapatkan pada bulan November 2019 dengan melakukan observasi dan praktik pembelajaran secara langsung.

\section{Hasil dan Pembahasan}

Berdasarkan pemaparan sebelumnya, bahwa tujuan pada peneliatian adalah untuk menggambarkan metode cerita dengan rumus $5 \mathrm{w}+1 \mathrm{~h}$ yang difokuskan pada keterampilan berbicara, dengan langkah praktek pembelajaran sebagai berikut:

1. Diawali dengan penjelasan secara umum tentang metode cerita dengan rumus $5 \mathrm{w}+1 \mathrm{~h}$, yang dijelaskan oleh pengajar itu sendiri.

2. Pengajar membacakan sebuah cerita tertulis dari buku ABY (Arabiyyah Baina Yadaik) dan para pembelajar menyimak dengan seksama

3. Kemudian menjelaskan maksud dari $5 \mathrm{w}+1 \mathrm{~h}$ yang ada pada cerita yang dibacakan, guna memudahkan pembelajar lebih faham tentang maksud metode ini.

4. Setelah membacakan cerita tertulis ABY (Arabiyyah Baina Yadaik), guru menambahkan cerita yang berfokus pada media gambar.

5. Guru menceritakan dengan semenarik mungkin guna menjadikan pembelajar dapat masuk dalam cerita yang diceritakan oleh guru.

6. Setelah usai menceritakan dengan menggunakan media gambar, guru menjelaskan kembali maksud dari $5 \mathrm{w}+1 \mathrm{~h}$ (semakin faham pembelajar tentang $5 \mathrm{w}+1 \mathrm{~h}$ maka akan memudahkan pembelajar dalam mengembangkan ide cerita nya menggunakan Bahasa Arab).

7. Guru memberikan waktu untuk pembelajar, guna menyiapkan ceritanya.

8. Guru tidak langsung menunjukan pembelajar dalam mempraktekkan metode ini. Dengan menggunakan permainan dalam pemilihan pembelajar, akan membuat kelas menjadi hidup dan tidak membosankan.

9. Permainan yang digunakan menggunakan permainan stick talking, dengan menggunakan pulpen yang digiring dan diiringan dengan lagu.

10. Peserta didik yang mendapat pulpen tersebut, dianjurkan untuk menceritakan sesuai dengan yang digambar dengan menggunakan rumus $5 \mathrm{w}+1 \mathrm{~h}$. (sampai seterusnya)

11. Evaluasi dari guru pun tetap menanyakan letak rumus $5 \mathrm{w}+1 \mathrm{~h}$ dari cerita yang diceritakan.

Sejatinya langkah-langkah pembelajaran dengan metode cerita memang berbeda dengan pemaparan yang telah dipaparkan para ahli sebelumnya. Disini penulis menggambarkan langkah-langkah pembelajaran yang terjadi pada lapangan secara langsung. Menurut teori dari para ahli langkah yang disuguhkan hanya 7 langkah akan 
tetapi, penulis memiliki pendapat yang berbeda pada penyuguhan metode cerita ini. Penulis menyuguhkan 11 langkah beserta dengan evaluasi yang sesuai.

Penulis mempertegas bahwa antara teori para ahli dan yang terjadi pada lapangan sejatinya tak jauh berbeda. Yang membedakan hanyalah beberapa penyampaian yang dilakukan oleh pembelajar itu sendiri bukan lagi pengajar sebagai panggung terpusat. Pengajar hanya sebatas pembuka sebuah show dalam kelas dan yang meramaikan panggung tersebut adalah para pembelajar itu sendiri.

Jika sebelumnya para ahli telah memaparkan metode cerita yang ditujukan pada anak usia dini, maka disini penulis akan menggambarkan berbagai bentuk yang terjadi pada lapangan yang menggunakan rumus $5 \mathrm{w}+1 \mathrm{~h}$. Dengan ini peneliti menemukan beberapa kelebihan dan kekurangan dalam metode cerita ini. Jika ditinjau dari segi kelebihan metode cerita ini, sebagai berikut:

1. Metode ini dapat meningkatkan 2 keterampilan yakni keterampilan menyimak dan keterampilan berbicara

2. Adanya metode ini membuat para penyimak mendapatkan sebuah informasi yakni kosakata baru dari pencerita yang ada didepan

3. Menjadikan peserta didik lancar dalam bercerita menggunakan Bahasa Arab.

4. Dengan menggunakan metode yang menggunakan rumus $5 \mathrm{~W}+1 \mathrm{~h}$ ini, pembelajar lebih mudah dalam mengembangkan ide ceritanya

5. Membuat peserta didik lebih berani dalam bertanggung jawab atas cerita yang diceritakan

Jika dilihat dari segi kekurangan dari metode cerita ini adalah sebagai berikut;

1. Perlu waktu yang lama dalam membuat sebuah cerita

2. Membutuhkan informasi terbaru

3. Mudah menjadikan peserta didik jenuh, jika cerita yang dibawakan tidak menarik.

4. Kurangnya referensi dalam membuat cerita, mengakibatkan pendengar tidak dapat masuk dalam cerita tersebut.

Dari kelebihan dan kurangan yang telah dipaparkan diatas, bahwa terdapat pembeda dengan pendapat para ahli. Sebelumnya para ahli menegaskan bahwa kekurangan dari metode cerita adalah tidak dapat mengembangkan kekreatifitasan pembelajar, maka disini berbanding terbalik dengan apa yang ada pada lapangan. Pada lapangan pembelajaran, pembelajar dapat berperan aktif dan dapat pula bertukar argument dengan sesama pembelajarnya.

Pada kekurangan pertama dalam metode ini penulis memparkan bahwa membutuhkan waktu yang lama dalam merangkai sebuah cerita, karena seperti yang telah dijelaskan oleh Djuraid sebelumnya bahwa penggunaan rumusan $5 \mathrm{w}+1 \mathrm{~h}$ memerlukan kesiapan yang matang dan bukan hanya sekali gali kemudian langsung menemukan ide cerita yang akan disuguhkan, melaikan penutur perlu membuat alur yang menarik dan mengesankan bagi para penyimaknya. Alur yang menarik itu dapat terbantu oleh adanya pertanyaan pada rumusan $5 \mathrm{w}+1 \mathrm{~h}$.

Dipertegas oleh Mudini dan Purba bahwa perlu adanya informasi baru bagi yang dapat dipahami oleh penyimaknya. Dengan ini penulis dapat menggambarkan bahwa yang terjadi dilapangan memerlukan waktu lama guna dapat menyuguhkan ide cerita yang menarik dan bukan hanya bermodalkan cerita menarik saja untuk penyimkanya, melaikan perlu adanya kemenarikan dalam penyampaian serta pemberian informasi barunya.

Para ahli pun menegaskan bahwa kekurangan metode ini juga terletak pada penuturnya jika penuturnya tidak dapat menceritakan dengan menyenangkan dan menarik maka akan membuat pembelajar menjadi jenuh dan ini sesuai dengan apa yang terjadi pada lapangan. Suatu alur yang menyenangkan akan menumbuhkan rasa keingintahuan yang lebih dalam mendengar cerita. Untuk itu, pengembangan cerita dirasa sangat perlu adanya dalam menceritakan sebuah kisah. 


\section{Kesimpulan}

Secara umum penulis akan menyimpulan dari pemaparan yang telah dibahas sebelumnya. Dalam metode cerita ini lebih dipentingkan pada anak usia dini, akan tetapi orang dewasa pun tidak akan bosan jika mendengar seuatu cerita atau menceritakan suatu cerita. Untuk itu penulis menyimpulkan bahwa pengaplikasian metode ini memang terdapat beberapa kelebihan dan kekurangannya sesuai yang telah dijelaskan sebelumnya. Yang dimana gambaran ketika dilapangan dan teori yang ada terkadang masih berbading terbalik. Dengan kata lain, teori yang ada tidak sesuai dengan keadaan pada lapangan.

Adanya metode cerita ini, penulis dapat menggambarkan bahwa pembelajar mulai merasa nyaman dengan cerita yang dituturkan menggunakan bahasa Arab dan dapat pula memudahkan pembelajar dalam mengembangkan ide-idenya dengan menggunakan rumus $5 \mathrm{~W}+1 \mathrm{~h}$.

\section{Daftar Pustaka}

Ahmad, Izzan. 2011. Metodologi Pembelajaran Bahasa Arab. Bandung: Humaniora Arikunto, Suharsimi. 1996. Prosedur Penelitian. Jakarta: Rineka Cipta.

Aini, Karina Nur. 2018. Metode Cerita dan Pengaruhnya dalam Pembelajaran Keterampilan Berbicara di PPBA A1 UIN Malang. (Skripsi) Malang: UIN Maulana Malik Ibrahim

Darmila, Lilis, Humaidah Br. \& Nunzairini. 2018. "Pengaruh Metode Bercerita terhadap Kosakata Anka Usia 5-6 Tahun Di RA Hajjah Siti Syarifah Kecamatan Medan Tembung”. Raudhah: 6 (01)

Djamarah, Syaiful Bahri. 2006. Strategi Belajar Mengajar. Jakarta: PT Rineka Cipta

Djuraid, Husnun N. 2007. Panduan Menulis Berita. Malang: UMM Press

Gunarti, Winda \& Azizah Muis. 2010. Metode Pengembangan Perilaku dan Kemampuan Dasar Anak Usia Dini. Jakarta: Universitas Terbuka

Harahap, Arifin S. 2006. Jurnalistik Televisi: Teknik Memburu dan Menulis Berita. Jakarta: PT Indeks Kelompok Gramedia.

Haryadi \& Zamzani. 2000. Peningkatan Keteranpilan Berbahasa Indonesia. Jakarta: Depdikbud

Hermawan, Acep. 2011. Metodologi Pembelajaran Bahasa Arab. Bandung: Rosdakarya

Hanik, Mahliatussikah. 2018. "Bermain, Cerita \& Menyanyi (BCM) Dalam Pembelajaran Bahasa Arab”. Prosiding Konferensi Nasional Bahasa Arab IV

Madyawati. 2016. Strategi Pengembangan Bahasa Pada Anak. Jakarta: Prenada Group

Moeslichatoen R. 2004. Metode Pengajaran di Taman Kanak-Kanak. Jakarta: PT Asdi Mahasatya

Mudini \& Salamat Purba. 2009. Pembelajaran Berbicara. Jakarta: Depdiknas

Nani, Kusnaini. 2004. Teknik Bercerita. Jakarta: Proyek Pengembangan Anak Dini Usia Pusat

Patimah. 2015. "Efektivitas Metode Pembelajaran Dongeng Dalam Meningkatkan Kemampuan Literasi Anak Pada Jenjang Usia Sekolah Dasar”. Al Ibtida: Jurnal Pendidikan Guru MI: 2 (2)

Romly, Asep Syamsudin M. 2000. Jurnalistik Praktis. Bandung: PT Remaja Rosdakarya.

Suhartono. 2005. Pengembangan Keterampilan Bicara Anak Usia Dini. Jakarta: Direktorat Jendral Pendidikan Tinggi

Sugiyono. 2011. Metode Penelitian Pendidikan. Bandung: Alfabeta

Taufik. 2016. Pembelajaran Bahasa Arab MI. Surabaya: UIN Sunan Ampel Press 
Nuraini \& Fitriani

Utami, Rima Andita. 2011. Peningkatan Keterampilan Menulis Cerpen Melalui Teknik $5 w+1$ h Dengan Media Video Klip Siswa Kelas X-6 Negeri 1 Bergas Kabupaten Semarang. (Skripsi). Semarang: Universitas Negeri Semarang 